Snežana Soković, LL.D.*

ПРЕГЛЕДНИ НАУЧНИ ЧЛАНАК

Full Professor,

doi:10.5937/zrpfni1775145S

Faculty of Law, University in Kragujevac

Veljko Turanjanin, LL.D.

UDK: 343.139

Assistant Professor,

Faculty of Law, University in Kragujevac

Dragana Čvorović, Ph.D.

Assistant Professor,

Academy of Criminalistic and Police Studies, Belgrade

\title{
MAIN HEARING ACCORDING TO THE NEW SERBIAN CRIMINAL PROCEDURE CODE: SURVEY IN PRACTICE
}

\begin{abstract}
The main hearing is the central part of the criminal procedure. In Serbia, the reform of the national criminal procedure legislation has brought about numerous changes related to this stage of criminal proceedings. Numerous objections have been addressed to the almost entirely new legal text. In an attempt to examine the advantages and disadvantages of the new legislation and observe how the prescribed rules are applied in practice, the authors have conducted an empirical research by attending 205 main hearings which were conducted under the rules of the new Criminal Procedure Code. The research covers a huge number of related issues but, given the page limit, this paper will focus on individual issues observed in trial proceedings. The focal point of reference is the examination of witness, but the authors also consider a number of other issues: the examination of expert witness, the delay of the trial, and the use of a video-link as a novelty introduced owing to the technological achievements of the modern era. The article is organized into several parts. The authors first provide a theoretical background of the issue under consideration and, then, present and discuss the research results provided in tables. In the third part of the article, the authors draw specific conclusions about the current practice in trials proceedings.
\end{abstract}

Keywords: main trial, examination of witnesses, examination of expert witnesses, cross-examination, use of video-link.

\footnotetext{
*ssokovic@jura.kg.ac.rs

vturanjanin@jura.kg.ac.rs

dragana.cvorovic@kpa.edu.rs
} 


\section{Introduction}

The process of reforming the criminal proceedings in Serbia is anything but a new topic in the scientific circles. The new Criminal Procedure Code (hereinafter: CPC), which entered into force in 2013, brought about a series of decisions and changes that follow the global trend of increasing efficiency. However, a multitude of solutions in the new legal text can reasonably be called into the question. As very correctly observed, the speed of a criminal procedure should not be equated with its efficiency because they are two completely different concepts; it is essential that criminal proceedings should not last longer than is objectively necessary whereas the time required for that is a factual matter (Škulić, 2011: 90). The speed of the proceedings is a relative category because the length of procedure depends on many factors, such as: the complexity of the evidence, the number of accused persons, possible changes in the composition of the judicial panel which are sometimes inevitable, and a number of other elements that make a particular case more or less complex or, on the contrary, relatively simple (Škulić, 2015: 42). Unfortunately, although the proceedings may look more efficient, we bear witness to the fact that they last much longer than it was the case with the former CPC.

The new CPC has been exposed to ample criticisms, which has generated the need for a more extensive study on its practical application (Soković, Čvorović, Turanjanin, 2016). The largest part of this research focuses on the subject matter of the main hearing, which is mostly based on the adversarial model (Škulić, 2016: 68-69). During the year 2015, we attended 205 trials in the Republic of Serbia, in the cities of Belgrade, Niš, Novi Sad and Kragujevac. We completed questionnaires for each individual main hearing in trial proceedings that we attended. The largest part of the questionnaire focused on the examination of witnesses, the cross-examination of expert witnesses, the postponement of the trial, and the use of the video-link. We have analyzed concrete data through 18 tables, where we introduced the question dealt with in each table and listed specific information. Since the focal point of this article is the empirical research, we will briefly explain the theoretical positions only where it is necessary.

\section{Witness examination}

The examination of witnesses is an extremely serious evidentiary action, which can be divided into four phases: asking general questions and taking the witness's free statement about everything that he/she knows about the case; the stage of primary/direct examination; the stage of cross-examination; and the phase of asking additional questions (Bugarski, Škulić, 2015: 275; Bugarski, 2013). 
The collected evidence is presented by the parties in trial proceedings, whereas the sequence of questions addressed to the witness depends on which party is first to examine the particular witness (Bejatović, 2015: 27). According to the $\mathrm{CPC}$, after hearing the accused (defendant), the presiding judge determines the sequence of presenting evidence, usually starting from the presentation of evidence proposed by the prosecutor, which is followed by the presentation of evidence proposed by the defense, then the evidence whose performance is determined ex officio and at the proposal of the victim and, finally, the evidence regarding the decisive facts that serve as grounds for the decision on the type and extent of criminal sanction. If there are legitimate reasons, the presiding judge may order a different sequence and prolong the time for presenting evidence (Article 396 para. 1 CPC).

In the research sample, the examination of witnesses was used at 185 main hearings; it was only in a few cases that the proceedings first involved the examination of defense witnesses, after which the prosecution witnesses were questioned. This means that the CPC rules were mostly complied with but also that there were cases where there were unjustified discrepancies.

\begin{tabular}{|lc|}
\hline \multicolumn{1}{|c|}{ 1. In what order were the witnesses questioned? } \\
\hline & Total \\
Any questioning of witnesses & 185 \\
There was no questioning of witnesses & 20 \\
\hline
\end{tabular}

At the outset, the witness is asked for general data, which was done in $100 \%$ of cases in our research. According to the CPC, the witness is examined individually and without the presence of other witnesses. The witness is obliged to testify orally. After general questions, the witness is invited to present everything that he/she knows about the case (Article 98 paragraphs 1-2 CPC) ${ }^{1}$. In our research, the legal rules were complied with at the highest percentage; however, one may pose a reasonable question why the witness was not allowed to say what he/she knows in the remaining $2.5 \%$ of cases. The rules on the examination of

1 On the one hand, there is a perception in the jurisprudence that the witness who (during the immediate statement) speaks only about essential things, while leaving out the peripheral ones, is not objective and cannot be trusted; on the other hand, if a witness is allowed to tell everything he/she knows about the case, the it may affect the concentration of the judicial panel who may lose track of some important facts. Therefore, there is the question of how to focus the witness's testimony on the important issues and leave out the less important ones, but without concurrently calling into question the credibility of the witness and his/ her testimony. Hence, the witness should be well prepared for the upcoming testimony (Tintor, 2013: 75). 
witnesses are more than clear; they refer to the complete testimony of what the witness saw or noticed.

\begin{tabular}{|lcc|}
\hline \multicolumn{4}{|c|}{ 2. Was the witness allowed to tell everything he/she knew? } & \\
Yes & Percentage & Total \\
No & $97,3 \%$ & 180 \\
& $2,7 \%$ & 5 \\
& Answered & $\mathbf{1 8 5}$ \\
Skipped & $\mathbf{2 0}$ \\
\hline
\end{tabular}

The witness shall always be asked how he/she knows what he is testifying about (Article 98 para.4 of the CPC). The research results clearly indicate the fact that this is a legal rule that is almost never complied with in practice. The answer to this question is used for determining the credibility of the witness, assessing the value of the witness testimony, and it concurrently prevents witnesses from presenting their opinions rather than sensually observed facts (Bejatović, 2014: 310 ). In as many as $71.4 \%$ of observed cases (or 132 proceedings), the witnesses were not asked how they had found out or knew what they were testifying about. While this finding stands as a surprise, it shows the completely unjustified circumvention of a clear and simple rule.

\begin{tabular}{|lcc|}
\hline \multicolumn{3}{|l|}{ 3. Was the witness asked how he/she had found out or knew what he/she } \\
was talking about? & Percentage & Total \\
Yes & $28,6 \%$ & 53 \\
No & $71,4 \%$ & 132 \\
& Answered & $\mathbf{1 8 5}$ \\
& Skipped & $\mathbf{0}$ \\
\hline
\end{tabular}

During the examination of a witness, primary/direct questions should be asked first, which are then followed by cross-examination and, finally, the witness is asked additional questions. The aim of asking questions is to check, supplement and clarify the given testimony (Đurđić, 2013: 96). As the survey results show, in $63.8 \%$ of the observed main trial proceedings, the witness was asked additional questions to clarify the given statements. The results show that the witnesses deviated from the previously given testimony in only 5, $4 \%$ of cases. It is not a large percentage, as there is always a possibility for a witness to change the testimony given in investigation proceedings, particularly in cases involving certain violent crimes. 


\begin{tabular}{|lcc|}
\hline \multicolumn{2}{|l|}{ 4. Was the witness asked additional questions? } & \\
Yes & Percentage & Total \\
No & $63,8 \%$ & 118 \\
& $36,2 \%$ & 67 \\
& Explanation & 8 \\
& Answered & $\mathbf{1 8 5}$ \\
Skipped & $\mathbf{2 0}$ \\
\hline
\end{tabular}

As required by the logic and legal knowledge, when one gets an opportunity for cross-examination, he/she must always bear in mind the fact that the witness was proposed by the opposing party and that this person may be hostile or antagonistic; for this reason, it is especially important to make the right decision whether to use the right to cross-examination after all. In our legal system, and in the comparative law (Friedland, 2014: 499; Sevier, 2016: 644-692), the crossexamination is not commonly used in practice. It is noted that cross-examination can be a powerful tool in the hands of a skilled lawyer because "the opportunity to ask leading questions provides counsel with the advantage of challenging a witness's statement on his or her own terms; furthermore, in some cases cross-examination may be the only means to obtain favorable evidence, attack unfavorable evidence or discredit a witness or witnesses (Brauti, 1997: 70).

However, the cross-examination is not without its limits (Sanders, 2016: 127128 ) and, in most cases, it cannot expose the false testimony, which could lead to wrongful conviction (Roth, 2016: 767-768). In other words, we should not forget the fact that this way of examination is not a very powerful weapon and that in practice, unlike in American films, it does not lead to any spectacular results. Delibašić states that one should observe the situation realistically and answer two basic questions beforehand: whether the supported thesis is at all compromised by the evidence arising from the basic examination and whether one can realistically expect to get the statement from the person in question that will support the thesis. The negative answer to any of these questions entails a consequence that it is better not to indulge in cross-examination (Delibašić, 2015: 224-225; Wellman, 2012: 8). When it comes to cross-examination, one should also take into account the fact that the opposite party has the right to additional questions, subject to approval of the presiding judge, which can neutralize the effects that have been achieved in cross-examination, as is the case when the cross-examination of the evidence results in the statement that differs from the testimony given during the investigation or at the basic examination, which may ultimately lead to the conclusion that a person is not telling the truth, and during a re-examination he or she is to provide a logical and reasoned expla- 
nation, whereby they need to precisely explain which statement is accurate (Delibašić, 2014: 78).

\begin{tabular}{|lcc|}
\hline \multicolumn{2}{|l|}{ 5. Did the court respond noting that the witness changed his/her testimony } \\
given earlier? & Percentage & Total \\
Yes & $5,4 \%$ & 10 \\
No & $94,6 \%$ & 174 \\
& Explanation & 4 \\
& Answered & $\mathbf{1 8 4}$ \\
& Skipped & $\mathbf{2 1}$ \\
\hline
\end{tabular}

If the witness departs from the testimony previously given, the presiding judge warns him of this and asks for the reasons for deviations. This can be done at the request of the accused, and he may order that the previous statement or part of the statement should be read, or its visual or sound recording should be reproduced. Then, if necessary, especially if the witness's testimony is literally recorded in the minutes, the presiding judge may order that part of the minutes to be immediately read; moreover, if it is required by the parties or counsel, the reading is compulsory (Škulić, 2015: 208). Since the witnesses are persons who belong to different social structures, the questions should be asked clearly, precisely and above all in an understandable manner for the particular witness. However, as it is always possible that the witness did not understand the question asked, clarification is required. In our sample, in only $2.2 \%$ of the cases the questions asked were incomprehensible to the witness, which is certainly a positive result.

\begin{tabular}{|lcc|}
\hline \multicolumn{4}{|c|}{ 6. Was there any question that the witness did not understand? } \\
Yes & Percentage & Total \\
No & $2,2 \%$ & 4 \\
& $97,8 \%$ & 181 \\
& Answered & $\mathbf{1 8 5}$ \\
& Skipped & $\mathbf{2 0}$ \\
\hline
\end{tabular}

The process of Americanization of criminal procedure has contributed to the development of complaint of the opposite sides regarding the issues raised. In practice, it happens in a relatively insignificant number of cases, whereas in our sample it happened in $7.6 \%$ of cases or during the questioning of 14 witnesses. Out of that number, in $15.4 \%$ of cases, the complaint was argued in front of the witness, while in a much larger number of cases the decision was brought after 
the council had withdrawn. However, most commonly, either party challenges the statement as a whole or complains about its parts. Specifically, we need to emphasize that the court did not discuss individual complaints, which were generally ignored completely. Of course, in cases where the court decided on the complaint, the decision was formalized and entered into the record.

\begin{tabular}{|lcc|}
\hline \multicolumn{2}{|l|}{ 7. Did the opposing party complain about the permissibility of certain } \\
issues? & Percentage & Total \\
Yes & $7,6 \%$ & 14 \\
No & $92,4 \%$ & 171 \\
& Explanation & 8 \\
& Answered & $\mathbf{1 8 5}$ \\
& Skipped & $\mathbf{2 0}$ \\
\hline
\end{tabular}

\begin{tabular}{|lcc|}
\hline $\begin{array}{l}\text { 8. Did the Presiding Judge of the judicial council ex officio ban an issue as } \\
\text { impermissible? }\end{array}$ & Percentage & Total \\
Yes & $1,6 \%$ & 3 \\
No & $98,4 \%$ & 185 \\
Explanation & & 1 \\
& Answered & $\mathbf{1 8 8}$ \\
& Skipped & $\mathbf{1 7}$ \\
\hline
\end{tabular}

Although the authority of the presiding judge of the judicial council was more than reduced in the new concept of trial proceedings, he or she still has the possibility to ban the question as impermissible. However, in the examined sample, that possibility was used in only three (1.6\%) cases. Then, in $2.7 \%$ of cases the judicial judicial panel was required to reach a decision which, as expected, in all cases confirmed the decision of the presiding judge. In our opinion, at the end of this part of proceedings, no impermissible questions were allowed by the presiding judge.

\begin{tabular}{|lcc|}
\hline 9. Was the court asked to bring a decision? & \\
& Percentage & Total \\
Yes & $2,7 \%$ & 5 \\
No & $97,3 \%$ & 183 \\
Explanation & & 0 \\
& Answered & $\mathbf{1 8 8}$ \\
& Skipped & $\mathbf{1 7}$ \\
\hline
\end{tabular}


10. Did the court confirm or disprove the decision of the presiding judge?

$\begin{array}{ccc} & \text { Percentage } & \text { Total } \\ \text { Confirm } & 100,0 \% & 5 \\ \text { Disprove } & 0,0 \% & 0 \\ \text { Explanation } & & 0 \\ \text { Answered } & & \mathbf{5} \\ \text { Skipped } & & \mathbf{2 0 0}\end{array}$

\begin{tabular}{|c|c|c|}
\hline \multicolumn{3}{|c|}{$\begin{array}{l}\text { 11. In your opinion, was there any impermissible question that the } \\
\text { presiding judge allowed? }\end{array}$} \\
\hline & Percentage & Total \\
\hline Yes & $0,0 \%$ & 0 \\
\hline \multirow[t]{4}{*}{ No } & $100,0 \%$ & 185 \\
\hline & Explanation & 0 \\
\hline & Answered & 185 \\
\hline & Skipped & 20 \\
\hline
\end{tabular}

In accordance with the foregoing matters, the court banned a question on its own initiative only in only 2 cases.

\begin{tabular}{|lcc|}
\hline 12. Did the court ban any question on its own initiative? & \\
Yes & Percentage & Total \\
No & $1,1 \%$ & 2 \\
& $98,9 \%$ & 186 \\
& Explanation & 0 \\
& Answered & $\mathbf{1 8 8}$ \\
& Skipped & $\mathbf{1 7}$ \\
\hline
\end{tabular}

However, there was a noticeable activity of the court in the course of asking additional questions that led to clarifying the matter at issue; thus, the presiding judge asked an additional question in $19.1 \%$ of examined cases. It is important to note that further clarification of circumstances was needed because the court suspected that the defendant was tortured.

\begin{tabular}{|c|c|c|}
\hline \multicolumn{3}{|c|}{$\begin{array}{l}\text { 13. Did the court ask any additional questions or questions that serve to } \\
\text { clarify the matter? }\end{array}$} \\
\hline & Percentage & Total \\
\hline Yes & $19,1 \%$ & 36 \\
\hline \multirow[t]{3}{*}{ No } & $80,9 \%$ & 152 \\
\hline & Answered & 188 \\
\hline & Skipped & 17 \\
\hline
\end{tabular}




\section{Expert examination}

Although the focus of this research was on witnesses, we could not ignore the role of expert witnesses in trial proceedings. The key question in this field concerned the examination of an expert witness, which included reading the findings of his/her expertise and giving opinions in court. The CPC stipulates that the expert witness orally presents his/her findings and opinion, but he may be allowed by the judicial council to read written findings and opinions, which shall be entered in the case files (Article 402 of the CPC). In our research, slightly more than a half of the main hearings ( $54.2 \%$ of cases) included the examination of experts, who were questioned in $30,9 \%$ of cases, while their findings were only read in $69.1 \%$ of the cases.

\begin{tabular}{|lcc|}
\hline \multicolumn{1}{|c|}{ 14. Was the expertise done in the case in question? } & \\
Percentage & Total \\
Yes & $54,2 \%$ & 84 \\
No & $45,8 \%$ & 71 \\
& Answered & $\mathbf{1 5 5}$ \\
& Skipped & $\mathbf{5 0}$ \\
\hline
\end{tabular}

\begin{tabular}{|lcc|}
\hline $\begin{array}{l}\text { 15. Were the experts questioned in the primary and direct examination, or } \\
\text { were their findings only read by the court? } \\
\text { Percentage }\end{array}$ & Total \\
Questioned & $30,9 \%$ & 46 \\
Read & $69,1 \%$ & 103 \\
& Answered & $\mathbf{1 4 9}$ \\
Skipped & $\mathbf{5 6}$ \\
\hline
\end{tabular}

\section{The use of the video-link}

One of the most frequent topical issues in scientific meetings is the use of a videolink testimony in criminal proceedings. The video-link is used in the criminal proceedings as a technical tool to allow the participation of certain individuals who shall not appear in front of the court or other criminal procedure authorities. Accordingly, the video-link should provide distance participation in criminal proceedings (Ćorović, Šemović, 2015: 355). The CPC provides for the use of the video-link, i.e. the use of technical devices for audio-vidual transmission in the following cases: a) to examine a specific vulnerable witness, b) to examine a protected witness, c) to examine witnesses and experts outside the court; d) to maintain order at trial, and d) to facilitate the participation of the accused 
at the main hearing and his hearing before the second instance court (Ćorović, Šemović, 2015: 362). Unfortunately, none of the above techniques were used in the trial proceedings we attended.

\begin{tabular}{|lcc|}
\hline 16. Was the video-conferencing technique used? & \\
Yes & Percentage & Total \\
No & $0,0 \%$ & 0 \\
& $100,0 \%$ & 205 \\
& Answered & $\mathbf{2 0 5}$ \\
\hline
\end{tabular}

\section{The deferral of the main hearing}

The deferral and adjournment of trials is one of the largest problems in the criminal proceedings in Serbia. The absence of one of the main subjects (parties) almost inevitably leads to rescheduling the hearing. In case where the main hearing has to be discontinued, there is an undisputed intention of the legislator that the proceeding should be stayed (adjourned) rather than deferred; but, in practice, the adjournment is rarely used (Tadić, 2016: 452). However, in some parts of Serbia, the deferral rate has increased because of defendants' requests for court interpreters. This often happens in Novi Pazar and Niš, where the defendants who understand the Serbian language often ask to be provided with an interpreter for the Bosnian and Roma language in order to prolong the trial proceedings, which is often perceived as an abuse of the guaranteed defendant's rights in criminal proceedings. In our research sample, none of the main hearings that we attended were postponed due to requests for court interpreters, considering that the Court was aware of the reasons for which the defendants placed such a request.

\begin{tabular}{|lcc|}
\hline 17. Was the main trial postponed because the accused sought a court \\
interpreter? & Percentage & Total \\
Yes & $0,0 \%$ & 0 \\
No & $100,0 \%$ & 202 \\
& Answered & 202 \\
& Skipped & 3 \\
\hline
\end{tabular}

Another reason for postponements is failure of witnesses to appear in court. However, as shown in the table below, the main hearing was delayed only in $14.9 \%$ of the observed cases due to the non-appearance of witnesses. In cases 
where there was a delay, the witness was fined and the order for his apprehension was issued.

\begin{tabular}{|lcc|}
\hline \multicolumn{4}{l}{ 18. Was the main trial adjourned due to failure of the witness to appear? } \\
Percentage & Total \\
Yes & $14,9 \%$ & 30 \\
No & $85,1 \%$ & 171 \\
& Answered & 201 \\
& Skipped & $\mathbf{4}$ \\
\hline
\end{tabular}

\section{Conclusion}

The scrutiny and subsequent analysis of observed trial proceedings in several cities in the Serbia has shown a diversity in the implementation of the CPC as well as the unwillingness of certain parties to implement it; the most extreme situation may be illustrated by a case where the judge asked the parties if they wanted the case to be adjudicated according to the former or the new CPC?!

The most extensive part of the research was related to the examination of witnesses. When it comes to the order of presenting the evidence, the CPC was largely complied with. When it comes to allowing the witness to say everything he/she knows about the subject matter of his testimony, we noted a small percentage of main hearings where the witness was not permitted to do so. The rules on the examination of witnesses shall be observed, and there are no justified reasons for such practices. Then, in an extremely high percentage of main hearings, the witness was not asked how he had found out or knew what he/she was testifying about. We consider that it is completely unjustifiable to avoid asking such questions. In practice, these procedures should be changed so that the witness should always be asked how he knows or how he has found out what he is testifying about because the answers to these questions determine the quality of the evidence. In the main hearings, witnesses are examined in the course of primary/direct and cross-examination, and then they are asked additional questions. In our research, such a situation was observed in the largest number of main hearings; thus, we can draw a conclusion that the parties and the defense counsel thoroughly reviewed the evidence and the new rules of criminal procedure. Positive practice has been observed in terms of asking clear questions, given that witnesses were asked vague questions in a low percentage of cases. Objections on particular issues are indeed rare, but there are common objections pertaining to the witness statement in its entirety. Such objections are primarily raised by the defense counsels; in our study, we have not recorded such objections being raised by the prosecutors. The legislator has left the court 
quite a narrow margin for initiative but, regardless of that, the courts actually take the initiative, which is best illustrated by the additional questions to witnesses which serve to clarify the subject matter at issue.

As for the examination of expert witnesses, the research shows that it took place in $54.2 \%$ of the observed cases. Yet, out of that number, the experts actually testified in only $30.9 \%$ of the cases, whereas in other cases (whose percentage is not low), the expert witness testimony was merely read, along with the ascertainment of the expert that he or she confirms what was previously written or said. We believe that the experts should be questioned more frequently because it contributes to a better clarification of the factual grounds for decision-making processes.

Unfortunately, the technical devices available in the modern age are not sufficiently utilized in criminal proceedings. For example, the use of a video-link is almost nonexistent; it was not used in a single case under observation. Although the use of a video-link in criminal procedure is envisaged in the CPC as a possibility, it is still necessary to improve this area. As previously proposed, this area should be regulated as follows: a) the standards on the required equipment for the transmission of images and sound shall be meet; b) the standards on the "network" for transmission of images and sound shall be meet, c) the persons who are to handle the equipment shall have relevant qualifications; d) some technical issues relating to the credibility of the evidence obtained by using a video link have to be addressed, such as the question of ensuring the presence of judicial officials on the premises where a person is giving a witness statement, in order to ascertain that the statement is given freely (Ćorović, Šemović, 2015: 362).

A more frequent abuse of procedural law has been observed in practice, which comes into play in cases involving the postponement of trial proceedings. In certain areas of the country, the defendants more frequently ask for an official court interpreter, primarily for the Bosnian and Roma languages. This may lead to unjustified delays in the proceedings. Judges noted that the defendants in detention "were often taught" by other inmates how to delay the main trial proceedings. Therefore, judges have to prevent this phenomenon. In the observed sample, no hearing was postponed due to the fact that the defendant had asked for an interpreter. It is not uncommon for the hearing to be postponed due to the non-appearance of witnesses. For many years, it had been one of the main shortcomings of the criminal proceedings. However, the research results show that the total of $14.9 \%$ of cases postponed due to the witness's failure to appear cannot be considered negligible. 
From all the above, we can conclude that there are certain drawbacks when it comes to the areas that we explored in trial proceedings but, on the whole, there are no major problems in the implementation of the new CPC provisions. In our research, we have identified the major drawbacks but it is also necessary to emphasize that we should use the opportunities offered by modern technologies.

\section{References}

Bejatović, S. (2014). Krivično procesno pravo. Belgrade: Službeni glasnik.

Bejatović, S. (2015). Glavni pretres i njegov doprinos obezbeđenju suđenja u razumnom. In S. Bejatović, I. Jovanović, Glavni pretres i suđenje u razumnom roku: regionalna krivičnoprocesna zakonodavstva i iskustva u primeni. Belgrade: OSCE Mission to Serbia i Srpsko udruženje za krivičnopravnu teoriju i praksu, 9-33.

Brauti, P. (1997). Improper Cross-Examination. Criminal Law Quarterly 40/1997. Bugarski, T. (2013). Ispitivanje svedoka. Zbornik radova Pravnog fakulteta $u$ Novom Sadu 4/2013, 131-143.

Bugarski, T., Škulić, M. (2015). Krivično procesno pravo. Novi Sad: Pravni fakultet, Univerzitet u Novom Sadu

Ćorović, E., Šemović, A. (2015). Upotreba video-linka u krivičnom postupku. In S. Bejatović, Suđenje u razumnom roku i drugi krivičnopravni instrumenti adekvatnosti državne reakcije na kriminalitet. Zlatibor: Srpsko udruženje za krivičnopravnu teoriju i praksu, 355-368.

Delibašić, V. (2014). Unakrsno ispitivanje - pravila i izazovi. Žurnal za kriminalistiku i pravo 1/2014.

Delibašić, V. (2015). Unakrsno ispitivanje u krivičnom procesnom pravu Srbije. In S. Bejatović, I. Jovanović, Glavni pretres i suđenje u razumnom roku: regionalna krivičnoprocesna zakonodavstva i iskustva u primeni. Beograd: OSCE Mission to Serbia i Udruženje za krivičnopravnu teoriju i praksu,, 218-231.

Đurđić, V. (2013). Dokazne radnje. In S. Bejatović, M. Škulić, G. Ilić, Priručnik za primenu Zakonika o krivičnom postupku. Beograd: Udruženje javnih tužilaca i zamenika javnih tužilaca Srbije, 83-122.

Friedland, M. L. (2014). Searching for Truth in the Criminal Justice System. Criminal Law Quarterly 60/2014.

Roth, J. A. (2016). Informant Witnesses and the Risk of Wrongful Convictions. American Criminal Law Review 53/2016. 
Sanders, S. R. (2016). The Value of Confrontation as a Felony Sentencing Right. Widener Law Journal 25/2016.

Sevier, J. (2016). Popularizing Hearsay. The Georgetown Law Journal 104/2016, 644-692.

Soković, S., Čvorović, D., Turanjanin, V. (2016). Cooperation between Public Prosecutor and the Police in Serbia. Zbornik radova Pravnog fakulteta u Novom Sadu 3/2016, 783-860.

Škulić, M. (2015). Krivičnoprocesno zakonodavstvo Republike Srbije- normativni aspekt adekvatnosti ili neadekvatnosti državne reakcije na kriminalitet. In S. Bejatović, Suđenje u razumnom roku i drugi krivičnopravni instrumenti adekvatnosti državne reakcije na kriminalitet. Zlatibor: Srpsko udruženje za krivičnopravnu teoriju i praksu, 41-75.

Škulić, M. (2015). Dokazi i dokazni postupak na glavnom pretresu. In: S. Bejatović, I. Jovanović, Glavni pretres i suđenje u razumnom roku: regionalna krivičnoprocesna zakonodavstva i iskustva u primeni. Belgrade: OSCE Mission to Serbia and Serbian Association for the Criminal Legal Theory and Practice, 193-217.

Škulić, M. (2011). Osnovi uporednog krivičnog procesnog prava i osnovni problemi reforme krivičnog postupka Srbije. In Đ. Ignjatović, Kaznena reakcija u Srbiji. Beograd: Pravni fakultet, Univerzitet u Beogradu, 54-125.

Škulić, M. (2016). Stepen (ne)usaglašenosti krivičnog postupka Srbije sa evropskim standardima. In S. Bejatović, Evropske integracije i kazneno zakonodavstvo (poglavlje 23 - zakon, praksa i mere harmonizacije). Zlatibor: Srpsko udruženje za krivičnopravnu teoriju i praksu, 46-75.

Tadić, D. (2016). Neprekidnost glavnog pretresa - norma i praksa. In S. Bejatović, Evropske integracije i kazneno zakonodavstvo (poglavlje 23 - Zakon, praksa i mere harmonizacije). European Integrations and Criminal Law Legislation (Chapter 23 - Norm, Practice and Harmonization Measures). Zlatibor: Srpsko udruženje za krivičnopravnu teoriju i praksu, 446-454.

Tintor, J. (2013). Branilac. In S. Bejatović, M. Škulić, G. Ilić, Priručnik za primenu Zakonika o krivičnom postupku. Beograd: Udruženje javnih tužilaca i zamenika javnih tužilaca Srbije, 59-82.

Wellman, F. (2012). The Art of Cross-Examination. New York. 


\section{Др Снежана Соковић, \\ Редовни професор Правног факултета, Универзитет у Крагујевиу \\ Др Вељко Турањанин, \\ Доцент Правног факултета, Универзитет у Крагујевиу \\ Др Драгана Чворовић, \\ Доцент Криминалистичко-полищијске академије у Београду}

\section{ГЛАВНИ ПРЕТРЕС ПРЕМА НОВОМ ЗАКОНИКУ О КРИВИЧНОМ ПОСТУПКУ: ИСТРАЖИВАЊЕ У ПРАКСИ}

\section{Сажетак}

Главни претрес представља централни део кривичног поступка. Реформом кривичног процесног законодавства у Србији унете су, између осталог, и бројне промене када је у питању ова фаза кривичног поступка. Готово целокупном новом законског тексту упућене су бројне примедбе. Услег тога, аутори су извршили истраживање пратећи 205 главних претреса који су одржани по правилима новог Законика о кривичном поступку, покушавајући да сагледају предности и недостатке, те како се правила примењују у пракси. Будући да је за обим рада било изузетно тешко обрадити сва питања, аутори су се базирали на поједина питања на главном претресу. Акценат је стављен на испитивање сведока, али нису занемарена ни питања вештачења, одлагања главног претреса, те употребе видео-линка, као новине захваљујући техничким достигнућима савременог доба. Аутори рад деле у више целина, теоретски образлажући питање о којем се баве, а потом табеларно представљајући резултате истраживања. На основу тога, на крају рада изводе конкретне закључке о досадашњој пракси вођења главних претреса.

Кључне речи: главни претрес, испитивање сведока, испитивање вештака, унакрсно испитивање, употреба видео-линка. 